\title{
O estranho, meu irmão ${ }^{1}$
}

\section{Liana Pinto Chaves ${ }^{2}$}

$\mathrm{O}$ estranho que veio ao nosso banquete, Mariano, traz para o nosso encontro um prato refinado: oferece para nossa degustação um trabalho engenhoso, elegante, sofisticado, sem gordura. É simples e claro, em toda a sua complexidade, se deixa ler com avidez, como as próprias histórias de detetive que tanto amamos.

A instrução que me foi dada para esta participação foi: posso pegar qualquer aspecto que eu quiser para começar a conversa. Pois bem, escolhi o vértice da esperança que o texto nos passa, diante de uma tarefa bastante difícil, mas incontornável. Diz o Mariano: se desejamos que a psicanálise continue sendo contemporânea, isso nos põe diante da tarefa de construir uma escuta que resgate o melhor da tradição, mas que não fuja do desconcerto. Muito pelo contrário, ele prega o exercício do desconcerto como prática de não acomodação, até mesmo porque não tem como ser evitado. É o desconcerto tanto do analisando quanto do analista, habitantes do mesmo mundo e da mesma época. É a angústia do analista como parceiro de viagem. $\mathrm{O}$ analista não é mais um Virgílio seguro, mestre, que leva Dante ao bom termo de sua jornada. É preciso, segundo nosso autor, uma certa dose de coragem e intuição, que faça dos analistas verdadeiros detetives selvagens.

Mariano é muito bom nas tríades. Partindo da freudiana, a fundante, inibição, sintoma e angústia, ele nos propõe outras duas. O trio enigma, mistério e segredo correspondem aos paradigmas para as identidades mutantes do analista que ele nos apresenta. A terceira tríade é surpresa (assombro), desorientação (confusão) e desconcerto. Ele vai tecendo os vários fios entre elas que pivoteiam em torno a um afeto fundamental - a angustia, que, a despeito de todas as mudanças, continua a ser o norte magnético na orientação da nossa prática.

\footnotetext{
${ }^{1}$ Este trabalho foi apresentado em oficina sobre as plenárias no I Simpósio Bienal "O mesmo, o outro: Psicanálise em movimento" eixo "O analista desconcertado: mal estar e cínica" da Sociedade Brasileira de Psicanálise de São Paulo.

${ }^{2}$ Membro efetivo e analista didata da SBPSP, atual secretária de seleção do Instituto Durval Marcondes
} 
A elaboração em torno das tríades levou-o a desenhar três modelos para definir a identidade do analista ao longo da história, modelos que se sucedem mas que também coexistem em alguma medida.

Primeiro vem o paradigma do enigma e a leitura dos indícios, à la Sherlock Holmes, segundo um modelo distante, asséptico, intelectual. Freud, qual arqueólogo, lendo o sentido cifrado dos sintomas.

Nos anos 20, a coisa se complicou com a virada teórica trazida pela pulsão de morte. E aí entra o paradigma do mistério. Agora os detetives começam a se sujar, não têm mais a assepsia anterior, têm muito em comum com seus investigados. E o psicanalista, não é mais o detetive frio, da destreza intelectual. É mais um antropólogo forense que trabalha a cena do crime.

O terceiro paradigma, o do segredo, diz mais respeito ao que é subtraído da análise. Aproximamo-nos da espionagem. Sua inspiração já não vem mais dos romances policiais, e, sim, dos poetas, através do livro Detetives Selvagens, de Roberto Bolaño, em que dois poetas marginais se engajam em uma busca destinada ao fracasso. Este é um livro monumental, cifrado, que muito exige do seu leitor. Esse espírito traduz admiravelmente o nosso estado de desconcerto diante de um mundo que nos escapa. Bolaño disse que este livro era uma carta de amor à sua geração, ele que se foi tão cedo e que viveu tão intensamente.

Considero que Mariano também fez um recorrido amoroso da história da psicanálise, à sua maneira literária. Cito-o: “Aqui [quando nos apresenta o último paradigma] o desconcerto encontra o seu lugar, pois o analista converte seu próprio desconcerto em exercício desconcertante, enquanto se oferece como refúgio e espaço de construção de respostas provisórias e mutantes." O analista oferece a sua hospitalidade ao analisando, favorecendo que algo se forme.

Esta nova modalidade anseia por inventar coordenadas analíticas ali onde não existem; a escuta em tempos incertos que procura fazer nascer um espaço de análise onde os tempos não garantem nem favorecem. 
Em épocas passadas, a instituição psicanalítica era forte e firme, como a família e outras instituições. Ela nos dava certezas sobre o que era e o que não era esperado de nós como analistas. Pertencíamos a famílias analíticas claras, com figuras de autoridade que eram chefes de escola. Isto nos protegia do desconcerto. Dizia-se isto é psicanálise, isto não é psicanálise. Procurávamos nos adequar ao modelo e também tentávamos dar conta da nossa clínica segundo este mesmo modelo. A vantagem é que nos sentíamos amparados; a desvantagem é que esse modelo prevalente foi envelhecendo e agora temos que nos haver com perguntas para as quais não temos resposta pronta.

Já não faz mais sentido falar em interpretações certas ou erradas, pois não há modelo único que dê conta da angústia existencial do homem contemporâneo. O analista tem mais liberdade em sua clínica, mas também tem mais incertezas. Encontra-se em pleno desconcerto. Ele se vê na eterna encruzilhada edipiana: precisa reinventar sua própria clínica, sem jogar fora o patrimônio. (Thomas Mann disse em algum lugar: seguir um exemplo à sua própria maneira isso é tradição.)

Este encontro trata da sobrevivência da psicanálise com vitalidade em tempos sombrios, avessos ao pensamento. Estamos falando de uma psicanálise para o homem que não sabe o que fazer. E nisso o analista, profissional do incompleto, é seu irmão, mas tem princípios norteadores a serem repensados, reinvestidos e revitalizados.

Lendo este trabalho, fui fazendo um percurso associativo próprio. Bem ao modo contemporâneo fragmentário vou compartilhar com vocês as reverberações do texto do Mariano em mim.

Lembrei-me primeiro do título de um livro de uma analista italiana, de 1994, “As certezas perdidas da psicanálise clínica”. Nele, a autora, Stefania Manfredi, faz um questionamento, 60 anos depois, sobre a eficácia mutativa das interpretações de transferência, referindo-se explicitamente ao trabalho clássico, tão importante, de Strachey de 1933.

Lembrei-me também de um outro trabalho: O homem desbussolado, de Jorge Forbes, de 2004, que aborda as mesmas questões trazidas pelo Mariano e com a mesma orientação teórica, ainda que sem a mesma elegância, como o próprio título estrambótico indica. Nele é dito que a transformação dos laços sociais exige uma mudança no ato analítico. Fala da 
necessidade de encarar uma nova época que não é orientada pela figura do pai, que antes ocupava o topo da hierarquia; hoje vivemos em um mundo horizontalizado. Na globalização, o laço social se horizontaliza, os ideais se pulverizam. Se antes o problema era: como vou chegar lá? Hoje passou a ser: para onde devo ir?

Com o declínio da autoridade, o homem ficou desbussolado - sem o norte da mão do pai. E o psicanalista se vê igualmente diante da mesma incerteza e tendo que escolher entre os vários futuros que lhe são possíveis: sem pai, sem norte, sem bússola. Já não nos valemos mais daquela transferência forte, cheia de autoridade. Tudo é questionado, questionável. Por que?! Em nome de quê?!

Em seguida me lembrei de um outro livro 'Gen ética - escolhas que nossos avós não faziam', da geneticista Mayana Zatz, sobre as implicações dos avanços científicos extraordinários que aconteceram nas últimas décadas no campo da genética humana.

E, por fim, uma nota sobre o Observatório Psicanalítico, um empreendimento de analistas brasileiros que se encontram na web para discutir questões da atualidade, em geral angustiantes, desoladoras, que desafiam o pensamento: violência urbana, autoritarismo, arbitrariedades, injustiças, ameaças à integridade e à dignidade. Este observatório hospitaleiro conseguiu criar um espaço de reflexão que nos alivia da solidão e da impotência individual diante do mundo que nos coube habitar.

Para encerrar: minha idéia de esperança é a possibilidade de compartilharmos o desconcerto e disso surgir a força do pensamento. Mariano nos conduziu por um caminho interessante, divertido e angustioso, porque todos nos reconhecemos nele e todos partilhamos a mesma perplexidade e incompletude, mas encerra com uma nota de esperança e confiança na força da psicanálise e em sua capacidade de se reinventar continuamente sempre fiel a seus princípios, que sustentam o nosso pensar.

\section{Referências}

Manfredi, S. T. (1994). As certezas perdidas da psicanálise clínica, Imago, Rio de Janeiro Zatz, M. (2013). Genética: Escolhas que nossos avós não faziam, Globo, São Paulo. 